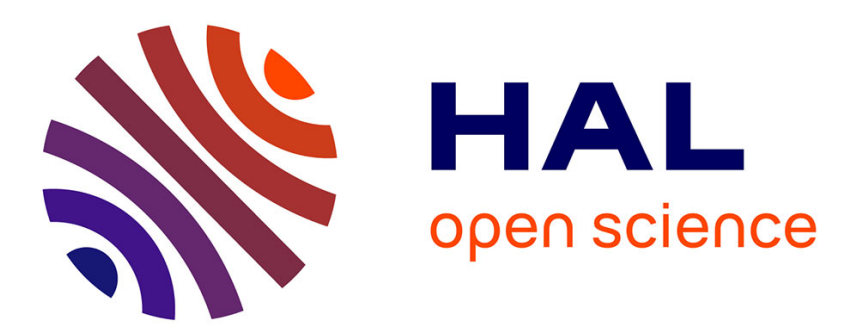

\title{
New data on gastrointestinal helminths in shags (Phalacrocorax verrucosus) at Kerguelen Archipelago
}

Frédéric Fonteneau, Timothée R. Cook

\section{To cite this version:}

Frédéric Fonteneau, Timothée R. Cook. New data on gastrointestinal helminths in shags (Phalacrocorax verrucosus) at Kerguelen Archipelago. Polar Biology, 2013, 36 (12), pp.1839-1843. 10.1007/s00300-013-1391-8 . hal-00943487

HAL Id: hal-00943487

https://hal-univ-rennes1.archives-ouvertes.fr/hal-00943487

Submitted on 7 Mar 2014

HAL is a multi-disciplinary open access archive for the deposit and dissemination of scientific research documents, whether they are published or not. The documents may come from teaching and research institutions in France or abroad, or from public or private research centers.
L'archive ouverte pluridisciplinaire HAL, est destinée au dépôt et à la diffusion de documents scientifiques de niveau recherche, publiés ou non, émanant des établissements d'enseignement et de recherche français ou étrangers, des laboratoires publics ou privés. 


\title{
New data on gastrointestinal helminths in shags (Phalacrocorax verrucosus) at Kerguelen Archipelago
}

\author{
Frédéric Fonteneau ${ }^{1}$, Timothée R. Cook ${ }^{2,3}$ \\ ${ }^{1}$ UMR CNRS Ecobio, Université de Rennes 1, Campus Beaulieu, Avenue du Général Leclerc, \\ 35042 Rennes cedex, France \\ ${ }^{2}$ Percy FitzPatrick Institute, DST/NRF Centre of Excellence, University of Cape Town, \\ Rondebosch 7701, South Africa \\ ${ }^{3}$ Centre d'Etudes Biologiques de Chizé, CNRS, UPR 1934, 79360 Villiers-en-Bois, France
}

Frédéric Fonteneau (corresponding author): frederic.fonteneau@gmail.com

Timothée R. Cook: timothee.cook@gmail.com 
Fonteneau, F. \& Cook, T.R. - New data on gastrointestinal helminths in shags (Phalacrocorax verrucosus) at Kerguelen Archipelago.

\section{Abstract}

To date, the knowledge of the helminth communities of Antarctic birds is scarce or fragmented. Knowledge about diseases and parasites is crucial for understanding and managing ecosystems, particularly in isolated areas where host species are more sensitive to new diseases or parasite infections. It has been showed that variations in rate of parasitism may occur between populations of host species. Two major non exclusive hypotheses have been proposed to explain such variability: exposure to parasitism and, perhaps more important, life history strategies of hosts. We studied the helminth community of the Kerguelen Shag Phalacrocorax verrucosus, an endemic seabird species of the Kerguelen Archipelago. We provide new data on the helminths infecting this species from partial or complete digestive tracts of two birds. Two nematodes (Contracaecum rudolphii s.l. and Ingliseria cirrohamata) were found free or attached to the wall of the proventriculus of birds, while the acanthocephalan Corynosoma sp. and the cestode species Tetrabothrius sp. occurred in the intestine of the shags. The genus Tetrabothrius is reported for the first time in Kerguelen Shags and in this area. The analysis of stomach contents from 41 live Kerguelen Shag individuals revealed infection by Contracaecum nematodes. The proportion of infected birds differed between colonies, possibly in relation to differential exposure to infected fish hosts.

Keywords: Nematoda, Cestoda, Acanthocephala, Southern Ocean, Cormorant, Seabird. 
Fonteneau, F. \& Cook, T.R. - New data on gastrointestinal helminths in shags (Phalacrocorax verrucosus) at Kerguelen Archipelago.

\section{Introduction}

Parasites can affect the population dynamics of their hosts. This may be determinant for isolated populations, and endemic or endangered species (e.g. Warner 1968) as a result of less developed immune defences (Lindström et al. 2004). To a large extent, bird and mammal species living in the Antarctic and sub Antarctic regions are endemic. To date, knowledge of the parasite fauna of these definitive hosts is virtually unknown (Barbosa and Palacios 2009), as are the processes of infection in these areas.

The Blue-eyed Shag complex is a group of 13 species exhibiting close morphological and behavioural characters, and which are loosely distributed around the Southern Ocean between roughly $40^{\circ} \mathrm{S}$ and $70^{\circ} \mathrm{S}$ (Orta 1992), in more or less complete isolation from one another. The Kerguelen Shag Phalacrocorax verrucosus (Cabanis, 1875) (Phalacrocoracidae: Cormorants) is a member of this species complex and is endemic to the Kerguelen Archipelago. This seabird is a marine piscivorous diver which feeds on fish from the Notothenioid sub-order (Cook et al. 2013), a group of benthic fish evolved in the Southern Ocean. Its population is estimated around 7000 breeding pairs (Weimerskirch et al. 1988), although this figure is probably approximate. The helminth fauna of this bird host is not well known. Three species are currently the only recorded parasites in Kerguelen Shags: the nematodes Ingliseria cirrohamata (Linstow, 1888) and Contracaecum rudolphii s.l. Hartwich, 1964, both first described in the Kerguelen Shag in the late $19^{\text {th }}$ century (Linstow 1888) and confirmed later (Cram 1927; Johnston and Mawson 1945) and one acanthocephalan species (Corynosoma clavatum Goss, 1940), described in the mid-20 $0^{\text {th }}$ century (Edmonds 1957). The aim of this work is to contribute to the knowledge of the gastrointestinal helminth community of Kerguelen Shags, and more largely of Antarctic and Subantarctic seabirds, and to discuss potential sources of infection. 
Fonteneau, F. \& Cook, T.R. - New data on gastrointestinal helminths in shags (Phalacrocorax verrucosus) at Kerguelen Archipelago.

\section{Materials and methods}

The study was carried out at the Kerguelen Archipelago $\left(49^{\circ} \mathrm{S}, 69^{\circ} \mathrm{E}\right)$ during the Austral summer from December 2005 to March 2006. Parasites came from two sources: live bird regurgitations and dead bird carcasses. Forty-one spontaneously regurgitated stomach contents were collected while handling 41 nesting birds upon their return from the sea (contents weighing less than $18 \mathrm{~g}$ were not kept for analysis). Stomach contents came from the Pointe Suzanne $(\mathrm{n}=18)$ and Sourcils Noirs $(\mathrm{n}=23)$ shag breeding colonies (colonies $30 \mathrm{~km}$ distant from one another, Fig. 1). In addition, the entire digestive tract of a fresh adult Kerguelen Shag found dead at Ratmanoff locality and the stomach (intestine too damaged for analyses) of one immature bird collected dead at Mayès were studied for parasitical examination (Fig. 1). After collection, carcasses and regurgitations were rapidly frozen and conserved at $-20^{\circ} \mathrm{C}$ until examination.

Samples were thawed at the laboratory. All worms were collected from regurgitates while these were sorted for diet analysis (Cook et al. 2013) using a binocular magnifying glass $(\times 2.5)$. Contents of digestive tracts were macroscopically examined. All worms collected in regurgitates and digestive tracts were counted, fixed in 10\% formalin, and stored in $70 \%$ alcohol before identification to genus or species level whenever possible. Parasite identifications were carried out using a list of specific bibliography on helminths of Subantarctic and Antarctic seabirds (e.g. Cram 1927; Johnston 1937a,b; Diaz et al. 2009) or Austral seabirds (e.g. Goss 1940).

Occurrence and intensity of infection in nematodes were tested using Chi-square test and Mann-Whitney test respectively

The study was approved by the French Ethic Committee of the Institut Polaire Paul-Emile Victor (IPEV) and by the Polar Environment Committee of the Terres Australes et Antarctiques Françaises (TAAF). 
Fonteneau, F. \& Cook, T.R. - New data on gastrointestinal helminths in shags (Phalacrocorax verrucosus) at Kerguelen Archipelago.

\section{Results}

During our study, only the nematode Contracaecum rudolphii sensus lato (s.1.) was found in the 41 regurgitates of nesting adults. In total, $34.1 \%$ of regurgitates contained parasites. Occurrence of infection was significantly different between colonies (Chi-square test: $\left.\chi^{2}(1)=4.36, \mathrm{p}<0.05\right)$ (Table 1$)$. Infection ranged between 0 and 28 nematodes per regurgitate and was also significantly different between colonies (Mann-Whitney test: $U(39)=129.5$, $\mathrm{Z}=-2.02, \mathrm{p}<0.05$ ) (Table 1). Four helminth genera (of which two were identifiable to the species level) were found in the digestive tract of the two carcasses of Kerguelen Shags. Two nematode species, Contracaecum rudolphii s.l. and Ingliseria cirrohamata, were found free or attached to the wall of the proventriculus of birds. Two genera, the acanthocephalan Corynosoma sp. and the cestode Tetrabothrius sp., occurred in the intestine of the shags. The digestive tract of the adult bird contained 1050 Tetrabothrius sp., 101 Contracaecum rudolphii s.1., 207 Ingliseria cirrohamata and 161 Corynosoma sp. The stomach of the fresh immature bird contained 289 Contracaecum rudolphii s.1. 
Fonteneau, F. \& Cook, T.R. - New data on gastrointestinal helminths in shags (Phalacrocorax verrucosus) at Kerguelen Archipelago.

\section{Discussion}

In all, only four genera of helminths (in which two species) were found in the Kerguelen Shag and more examinations will be necessary to confirm these results and to identify at specific level some of the species found. Despite a modest sample size, the helminth community of the digestive tract of the Kerguelen Shag appears poor compared to that of more northerly and continental Phalacrocoracidae species in which up to 17 species can occur, as in the Great Cormorant Phalacrocorax carbo in Europe (e.g. Švažas et al. 2011), the Double-crested Cormorant Phalacrocorax auritus in North America and the Neotropic Cormorant Phalacrocorax brasilianus in South America (e.g. Fedynich et al. 1997). The helminth richness in Kerguelen Shags is in accordance with the relatively low number of parasites species (from 3 to 6) found in other Sub-Antarctic and Antarctic piscivorous birds (Fonteneau et al. 2011; Vidal et al. 2012; Diaz et al. 2013). Such latitudinal differences in helminth diversity could result from the global tropic-to-pole diversity gradient (Turner 2004) and isolation of Sub-Antarctic and Antarctic species, leading to lower parasite richness in these regions.

Tetrabothrius sp. was present in the intestine of the adult Kerguelen Shag. This is the first report of this cestode genus in the Kerguelen Shag and in this geographical area. This genus occurs also in two other Phalacrocoracidae birds (the Double-crested Cormorant Phalacrocorax auritus and in the Antarctic Shag Phalacrocorax bransfieldensis) (Hoberg 1987) and throughout a wide range of Sub-Antarctic and Antarctic bird host species, like penguins (e.g. Fonteneau et al. 2011; Vidal et al. 2012) and petrels (e.g. Jones 1988). More investigations should be conducted to identify the status of the Tetrabothrius species infecting the Kerguelen Shag compared to other Tetrabothrius species found in other seabirds.

Our study reports for the second time acanthocephalans of the genus Corynosoma from the intestine of the adult Kerguelen Shag. Further investigations should be conducted to identify the status of the Corynosoma sp. found here compared to Corynosoma clavatum previously described in the Kerguelen Shag (Edmonds 1957).

The Acuariidae nematode Ingliseria cirrohamata was first described in the Kerguelen Shag at Kerguelen Archipelago (Linstow 1888; Cram 1927; Johnston \& Mawson 1945). Recently, this nematode was re-described with new samples from this type host and locality and in three other bird species (the Imperial Shag Phalacrocorax albiventer, the Neotropic Cormorant and the Magellanic Cormorant Phalacrocorax magellanicus) from two other 
Fonteneau, F. \& Cook, T.R. - New data on gastrointestinal helminths in shags (Phalacrocorax verrucosus) at Kerguelen Archipelago.

geographical localities (Argentina and Chile) (Diaz et al. 2009). In view of our results, infection intensity would seem more important in the Kerguelen Shag (up to 207 specimens in one bird) than in the three other definitive hosts (no more than four specimens per bird) (Diaz et al. 2009). However, no regurgitations of Kerguelen Shags contained Ingliseria cirrohamata and only one of the two carcasses was infected. This nematode does not seem a common parasite in this host. Indeed, only two specimens were found in the stomach of one bird during the first parasite exploration in this host species (Linstow 1888; Cram 1927) and later only one specimen was obtained in one of seven examined birds (Johnston and Mawson 1945).

Nematodes of the genus Contracaecum (Anisakidae) are known to commonly infect the Phalacrocoracidae family (e.g. Fedynich et al. 1997; Abollo et al. 2001; Dezfuli et al. 2002; Garbin et al. 2011). Contracaecum rudolphii s.l. was described infecting the Kerguelen Shag (Linstow 1888). It is now known that Contracaecum rudolphii s.l. is formed by a complex of several sibling species (e.g. Mattiucci et al. 2008; D'Amelio et al. 2012). The Contracaecum species found in the Kerguelen Shag during the present study was genetically analysed and identified as a new sibling species differing from those Contracaecum rudolphii s.l. known in other birds (Mattiucci et al. 2009). Further studies are needed to determine which morphological characteristics can be used to distinguish this species in the Contracaecum rudolphii complex in order to assign a formal name to it. We found this nematode at all sites, which is consistent with a previous study which reported it at "various localities in Kerguelen" (Johnston and Mawson 1945), suggesting it is distributed throughout the archipelago.

Contracaecum nematodes have been reported attached to the wall of the proventriculus of some piscivorous birds. This fastening of nematodes is thought to be an adaptation to counter the abrasive effect of fish bones resulting from digestion (Huizinga 1971; Liu and Edward 1971). Thus, this attachment seems to be effective only towards the end of the digestive period. During the digestive process, most nematodes are normally free and mixed to the stomach content. As regurgitates in the present study come exclusively from birds just returning from fishing areas, we assumed that nematodes were free in the stomach at the moment of regurgitation. Nevertheless, as spontaneous regurgitations represented a fraction of the stomach content, the number of nematodes collected per bird amounted only to a certain percentage of all the nematodes actually present in the whole stomach. Contracaecum rudolphii s.l. was found in the stomachs of the two carcasses from the present study, and in all seven birds examined previously by Johnston and Mawson (1945). However, occurrence of 
Fonteneau, F. \& Cook, T.R. - New data on gastrointestinal helminths in shags (Phalacrocorax verrucosus) at Kerguelen Archipelago.

this nematode in regurgitations ranged only from 17 to $48 \%$, depending on the colony. Also, Contracaecum numbers per regurgitations (from 0 to 28) were low compared to the numbers of nematodes found in the stomachs of the two carcasses (from 101 to 289). Obviously, the regurgitation method does not provide an absolute figure of the parasite load in the bird's stomach, but an estimate of the number per gram of food. The prevalence and intensity at Sourcils Noir colony were higher than at Pointe Suzanne despite the average mass of stomach content being lower at the former, suggesting that infection estimates were not biased by sample size. Even by extrapolating the number of parasites in each sample to the total theoretical mass of food per content, the number of parasites does not approach the number found in the stomach of the carcasses. Several hypotheses can be suggested to explain this discrepancy. First, not all Contracaecum are detached from the proventriculus when the bird's stomach is full. Second, the deaths of the two Kerguelen Shags found dead could be related to their high infections in Contracaecum. The first description of this nematode genus in Kerguelen Shags reports a bird with only 36 nematodes (Linstow 1888), suggesting that the numbers found in the two carcasses could be indeed higher than normal. Future investigations should focus on testing the efficiency of parasitical study of regurgitations as a nondestructive method to evaluate infection rates of stomach nematodes in piscivorous birds.

The diet of Kerguelen Shags is comprised of nearly $90 \%$ of nothotenioid fish species (Table 1), namely Lepidonotothen mizops, Notothenia cyanobrancha and Harpagifer sp. (Cook et al. 2013). In Sub-Antarctic and Antarctic areas, some nototheniid fish, amongst which the three genera Lepidonotothen, Harpagifer and Notothenia, were mentioned as vectors for larval stages of Contracaecum nematodes (e.g. Laskowski and Zdzitowiecki 2005; Rokicki et al. 2009). The dominance of Lepidonotothen mizops at Sourcils Noirs, the colony with the highest infection rates of Contracaecum in stomach contents (Table 1), points to a possible determining role of that fish species as a vector of Contracaecum rudolphii s.l., even if Notothenia cyanobrancha is also known as a possible vector for Contracaecum larvae in waters off Kerguelen Archipelago (Johnston and Mawson 1945). Fish of the family Nototheniidae, which are identified vectors for larval stages of ancanthocephalans of the genus Corynosoma (see Zdzitowiecki 1986 for review) and for cestodes of the genus Tetrabothrius (Hoberg 1987), could also play a similar role in the helminth infection of the Kerguelen Shags and other birds in Sub-Antarctic areas. Little is known about the life cycle of the genus Ingliseria. As all the definitive hosts in which this nematode species were described are fish-eating birds (Diaz et al. 2009), fish are also likely vector for Ingliseria cirrohamata. 
Fonteneau, F. \& Cook, T.R. - New data on gastrointestinal helminths in shags (Phalacrocorax verrucosus) at Kerguelen Archipelago.

\section{Acknowledgements}

The authors are grateful to the French Polar Institute (Institut Paul-Emile Victor - IPEV) and the Terres Australes et Antarctiques Françaises for financial and logistical means in the field. Field work was approved by the institute's ethics committee and was conducted under IPEV research program number 394 (Diving Seabirds, coordinator: Charles-André Bost). Thanks to John Mike Kinsella for his precious assistance in the identification of parasites and to two anonymous referees to their constructive comments and suggestions.

\section{References}

Abollo E, Gestal C, Pascual S (2001) Anisakid infection in the European shag Phalacrocorax aristotelis aristotelis. J Helminthol 75:209-214

Barbosa A, Palacios MJ (2009) Health of Antarctic birds: a review of their parasites, pathogens and diseases. Polar Biol 32:1095-1115

Cook TR, Lescroël A, Cherel Y, Kato A, Bost CA (2013) Can foraging ecology drive the evolution of body size in a diving endotherm? PLoS One 8:e56297

Cram EB (1927) Bird parasites of the suborders Strongylata, Ascaridata and Spirurata. Bull U S Natl Mus 140:1-465

D'Amelio S, Cavallero S, Dronen NO, Berros NB, Paggi L (2012) Two new species of Contracaecum Railliet \& Henry, 1912 (Nematoda: Anisakidae), C. fagerholmi n. sp. and C. rudolphii $\mathrm{F}$ from the brown pelican Pelecanus occidentalis in the northern Gulf of Mexico. Syst Parasitol 81:1-16

Dezfuli BS, Volponi S, Beltrami I, Poulin R (2002) Intra- and interspecific density-dependant effects on growth in helminth parasites of the cormorant, Phalacrocorax carbo sinensis. Parasitology 124:537-544

Diaz JI, Fonteneau F, Panisse G, Cremonte F, Navone GT (2009) Redescription of Ingliseria cirrohamata (Linstow, 1988) (Nematoda: Acuariidae), including new hosts and geographical records. J Parasitol 95:396-402

Diaz JI, Fusaro B, Longarzo L, Coria NR, Vidal V, Jerez S, Ortiz J, Barbosa A (2013) Gastrointestinal helminths of Gentoo penguins (Pygoscelis papua) from Stranger Point, 25 de Mayo/King George Island, Antarctica. Parasitol Res 112:1877-1881 
Fonteneau, F. \& Cook, T.R. - New data on gastrointestinal helminths in shags (Phalacrocorax verrucosus) at Kerguelen Archipelago.

Edmonds SJ (1957) Acanthocephala. BANZARE Rep (1929-1931) Ser B 6:93-97

Fedynich AM, Pence DB, Bergan JF (1997) Helminth community structure and pattern in sympatric populations of Double-crested and Neotropic cormorants. J Helminthol Soc Wash 64:176-182

Fonteneau F, Geiger S, Marion L, Le Maho Y, Robin JP, Kinsella JM (2011) Gastrointestinal helminths of King penguins (Aptenodytes patagonicus) at Crozet Archipelago. Polar Biol 34:1249-1252

Garbin L, Mattiucci S, Paoletti M, González-Acuña D, Nascetti G. (2011) Genetic and morphological evidences for the existence of a new species of Contracaecum (Nematoda: Anisakidae) parasite of Phalacrocorax brasilianus (Gmelin) from Chile and its genetic relationships with congeners from fish-eating birds. J Parasitol 97:476-492

Goss OM (1940) Platyhelminth and Acanthocephalan parasites of local shags. J Roy Soc West Aust 26:1-15

Hoberg EP (1987) Tetrabothrius shinni sp. nov. (Eucestoda) from Phalacrocorax atriceps bransfieldensis (Pelecaniformes) in Antarctica with comments on morphological variation, host-parasite biogeography, and evolution. Can J Zool 65:2969-2975

Huizinga HW (1971) Contracaeciasis in Pelecaniform birds. J Wildl Dis 7:198-204

Johnston TH (1937a) Cestoda. Aust Antarct Exped (1911-1914), Ser C, Vol X, Part IV

Johnston TH (1937b) Nematoda. Aust Antarct Exped (1911-1914), Ser C, Vol X, Part V

Johnston TH, Mawson PM (1945) Parasitic nematodes. BANZARE Rep (1929-1931) Ser B 5:74-159

Jones HI (1988) Notes on parasites in penguins (Spheniscidae) and petrels (Procellariidae) in the Antarctic and subantarctic. J Wildl Dis 24:166-167

Laskowski Z, Zdzitowiecki K (2005) The helminth fauna of some notothenioid fishes collected from the shelf of Argentine Islands, West Antarctica. Pol Polar Res 26:315-324

Lindström KM, Foufopoulos J, Pärn H, Wikelski M (2004) Immunological investments reflect parasite abundance in island populations of Darwin's finches. Proc R Soc Lond B 271:1513-1519

Linstow O (1888) Report on the entozoan collected by HMS Challenger during the years 1873-76. Rep Voyage HMS Challenger (1873-76) 23:1-18

Liu SK, Edward AG (1971) Gastric ulcers associated with Contracaecum spp. (Nematoda: Ascaroidea) in a Steller sea lion and a White pelican. J Wildl Dis 7:266-270 
Fonteneau, F. \& Cook, T.R. - New data on gastrointestinal helminths in shags (Phalacrocorax verrucosus) at Kerguelen Archipelago.

Mattiucci S, Paoletti M, Olivero-Verbel J, Baldiris R, Arroyo-Salgado B, Garbin L, Navone G, Nascetti G (2008) Contracaecum bioccai n. sp. from the brown pelican Pelecanus occidentalis (L.) in Colombia (Nematoda: Anisakidae): morphology, molecular evidence and its genetic relationship with congeners from fish-eating birds. Syst Parasitol 69:101-121

Mattiucci S, Paoletti M, Garbin L, Fonteneau F, Taccari C, Ruggiero L, Nascetti G, González-Acuña D (2009) Molecular evidence for new sibling species of Contracaecum rudolphii complex (Nematoda: Anisakidae) parasites of cormorants from the Austral hemisphere, and genetic relationships with congeners. V Congreso Argentino de Parasitología, 25-28 March 2009, La Plata-Buenos Aires, Argentina

Orta J (1992) Family Phalacrocoracidae (Cormorants). In Del Hoyo J, Elliott A, Sargatal J (eds) Handbook of the birds of the World. Vol. 1. Lynx Editions, Barcelone, pp 326-353

Rokicki J, Rodjuk G, Zdzitowiecki K, Laskowski Z (2009) Larval ascaridoid nematodes (Anisakidae) in fish from the South Shetland Islands (Southern Ocean). Pol Polar Res 30:4958

Švažas S, Chukalova N, Grishanov G, Pūtys Ž, Sruoga A, Butkauskas D, Raudonikis L, Prakas P (2011) The role of Great cormorant (Phalacrocorax carbo sinensis) for fish stock and dispersal of helminthes parasites in the Curonian Lagoon Area. Vet Med Zoot 55:79-85 Turner JRG (2004) Explaining the global biodiversity gradient: energy, area, history and natural selection. Basic Appl Ecol 5:435-448

Vidal V, Ortiz J, Diaz JI, de Ybañez MR, Amat MT, Palacios MJ, Benzal J, Valera F, de la Cruz C, Motas M, Barbosa A (2012) Gastrointestinal parasites in Chinstrap Penguins from Deception Island, South Shetlands, Antarctica. Parasitol Res 111:723-727

Warner RE (1968) The role of introduced diseases in the extinction of the endemic hawaiian avifauna. The Condor 70:101-120

Weimerskirch H, Zotier R, Jouventin P (1988) The avifauna of the Kerguelen Islands. Emu 89:15-29

Zdzitowiecki K (1986) Acanthocephala of the Antarctic. Pol Polar Res 7:79-117 
Fonteneau, F. \& Cook, T.R. - New data on gastrointestinal helminths in shags (Phalacrocorax verrucosus) at Kerguelen Archipelago.

Table 1. Characteristics of Kerguelen Shag stomach contents: prey and infection rates. The three most abundant prey species (amounting to almost $90 \%$ of all prey items) are presented (data from Cook et al. 2013). Occurrence is defined as the occurrence of the fish or parasite in the content relative to the total number of contents. Proportion is defined as the proportion of individuals from any prey species relative to the total number of prey items in all contents. Values are presented as average $( \pm \mathrm{SD})$ and range.

\begin{tabular}{lcc}
\hline & Sourcils Noirs & Pointe Suzanne \\
\hline Stomach content mass $(\mathrm{g})$ & $59 \pm 38(18-192)$ & $98 \pm 43(24-179)$ \\
Harpagifer sp. occurrence $(\%)$ & 46.1 & 38.9 \\
Harpagifer sp. proportion (\%) & 10.0 & 7.2 \\
Notothenia cyanobrancha occurrence $(\%)$ & 19.2 & 94.4 \\
Notothenia cyanobrancha proportion $(\%)$ & 3.5 & 74.0 \\
Lepidonotothen mizops occurrence $(\%)$ & 92.3 & 22.2 \\
Lepidonotothen mizops proportion $(\%)$ & 72.6 & 7.2 \\
Contracaecum rudolphii s.l. occurrence $(\%)$ & 47.8 & 16.7 \\
Contracaecum rudolphii s.l. per content & $4.2 \pm 7.3(0-28)$ & $0.2 \pm 0.5(0-2)$ \\
Contracaecum rudolphii s.l. per gram & $0.083 \pm 0.182(0-0.840)$ & $0.003 \pm 0.007(0-0.025)$ \\
\hline
\end{tabular}


Fonteneau, F. \& Cook, T.R. - New data on gastrointestinal helminths in shags (Phalacrocorax verrucosus) at Kerguelen Archipelago.

Fig. 1. Localisation of sampled sites at Kerguelen Islands during the breeding season 20052006. Mayès and Ratmanoff correspond to the names of the sites where the two dead shags were found near the shore. Pointe Suzanne and Sourcils Noirs correspond to the two shag breeding colonies where the regurgitated stomach contents were sampled.

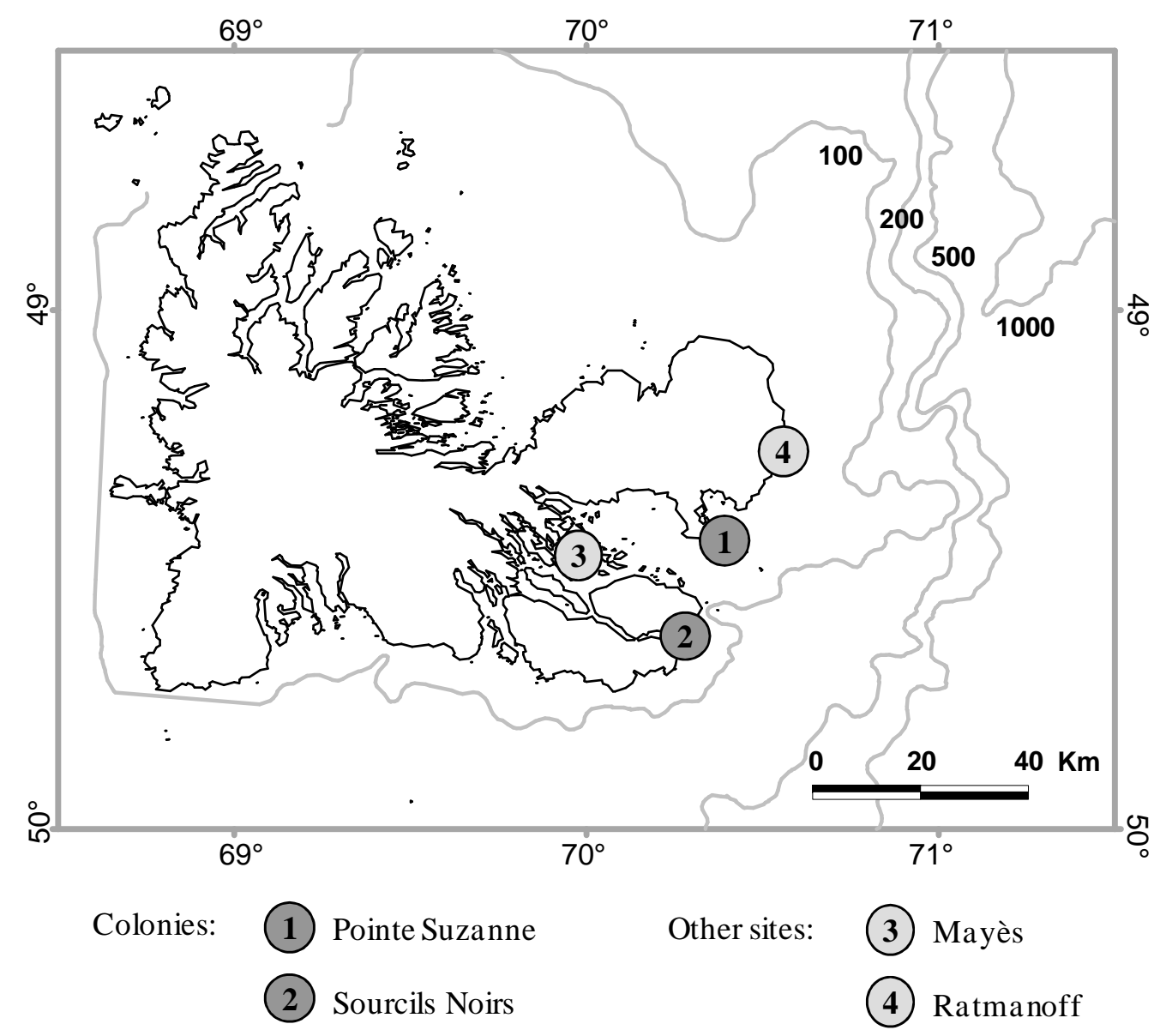

